\title{
Hybrid geothermal-PV-wind system for a village in Pakistan
}

\author{
Syed Wajjahat Saleem Kazmi ${ }^{1} \mathbb{D}$. Muhammad Imran Sheikh ${ }^{1}$
}

(c) Springer Nature Switzerland AG 2019

\begin{abstract}
Combining diverse sources of renewable power into a hybrid renewable energy system (HRES) has gained more attractions with the fast evolution of the renewable energy market. Renewable resources as alternative energy for electricity generation are the only way to cater to the present environmental and social challenges. An on-grid hybrid geothermalPV-wind system at Tattapani, Azad Jammu Kashmir, Pakistan, is considered, as enough geothermal energy is available from hot springs to cater for the perennial base load requirement of the small community. The paper presents HRES design with minimal net present cost (NPC), so that the PV and wind energy plants are used to complement the geothermal plant during high demand and to feed the grid during low-energy requirements. This results in reduced cost of electricity (COE) and the decrease in fossil fuel-reliant energy from the national grid, thus bringing prosperity for the poor people of the village and contributing to the reduction in global warming. Sensitivity analysis to the constraints such as solar irradiation, wind speed and interest rate is presented as well. The study showed that for Tattapani, an ongrid hybrid geothermal, PV and wind system with the capacity of $250 \mathrm{kw}, 250 \mathrm{kw}$ and $100 \mathrm{kw}$, respectively, is a feasible design with the NPC of 234.11 million rupees at the interest rate of $5 \%$. The system can fulfill the average load demand $7350 \mathrm{kWh} /$ day, while the surplus energy is sold to the grid. COE of the proposed system is $7.50 \mathrm{Rs} / \mathrm{kWh}$, and the system will also evade 1.8 million kilograms of $\mathrm{CO}_{2}$ along with other flue gas emissions to pollute the atmosphere. Sensitivity analysis shows that if wind speed varies from 4.5 to $6 \mathrm{~m} / \mathrm{s}$ while GHI remains constant, the cost of wind energy decreases from 20.08 to $12.5 \mathrm{Rs} / \mathrm{kWh}$. Similarly, if average GHI increases from 4.5 to $6 \mathrm{kWh} / \mathrm{m}^{2} /$ day and wind speed remains constant, the cost of solar energy decreases from 8.04 to $6.06 \mathrm{Rs} / \mathrm{kWh}$. If wind speed and GHI changes at the same time from 5 to $6 \mathrm{~m} / \mathrm{s}$ and $4.5 \mathrm{kWh} / \mathrm{m}^{2} /$ day to $6 \mathrm{kWh} / \mathrm{m}^{2} /$ day, respectively, NPC decreases from Rs 245 million to Rs 228 million keeping interest rate constant at $5 \%$. Another important result showed that when interest rate changes from zero to $20 \%$, overall NPC decreased from Rs294 million to Rs159 million and COE increased from 6.50 to $11.69 \mathrm{Rs} / \mathrm{kwh}$.
\end{abstract}

Keywords Azad Jammu Kashmir (AJK) - Capital recovery factor (CRF) - Levelized cost of energy (LCOE) - Global horizontal irradiance (GHI) · Greenhouse gasses (GHGs) · Hybrid renewable energy systems (HRES) · Initial capital (IC) . Annual operating cost $(\mathrm{AOC}) \cdot$ Net present cost (NPC)

\section{Introduction}

Every source of energy generation has its own impact on the environment whether it is renewable or fossil fuel. Conventional power plants that use fossil fuel harm the environment more as compared to the renewables. Water and air pollution, habitat and wildlife loss and public health deterioration are few of such environmental hazards [1].
Renewable resources, whether solar, wind, water or geothermal, are helpful in the generation of cleanest electricity. Wind, solar and hydropower plants have essentially zero emissions. As far as geothermal power plants are concerned, the closed-loop system geothermal plants have minimal emissions because gasses removed from well after giving up their heat are again injected into the ground. The open-loop geothermal plants emit carbon

$\triangle$ Syed Wajjahat Saleem Kazmi, syedwajahat60@gmail.com; Muhammad Imran Sheikh, drimran@uet.edu.pk| ${ }^{1}$ Department of Electrical Engineering, University of Engineering and Technology (UET), Lahore, Pakistan.

SN Applied Sciences (2019) 1:754 | https://doi.org/10.1007/s42452-019-0643-9 
dioxide, methane, ammonia and hydrogen sulfide. The percentage emission of $\mathrm{SO}_{2}$ in open-loop geothermal plants is still approximately 30 times per MWh less as compared to that of coal-fired plants. While $0.2 \mathrm{lb}$ per kilowatthour carbon dioxide is emitted by such plants, coal-fired plant's emission rate of $\mathrm{CO}_{2}$ per $\mathrm{KWh}$ is $1.4-3.6 \mathrm{lb}$. As far as impacts on the environment are concerned, renewable energy plants are the best possible choice. The only adverse impact on the environment by these plants is that some of these plants require a large area for their erection like hydropower plants [2].

Due to the variations in the output obtained from resources of renewable energy, different plants are combined to improve the overall reliability of the system. Research work related to HRES is being perused vigorously in different dimensions. Different techniques and software tools are available to techno-economically analyze and optimize the operation of HRES. Distributed energy resources customer adoption model (DER-CAM) technique used to determine the optimal size and operating schedule of a distributed energy resource (DER) is discussed in [3]. Techno-economic sizing of an off-grid PV-wind-diesel generator hybrid system for rural electrification is discussed in [4]. Another research work including review of different HRES sizing programs and detailed methodology of sizing a PV-wind system is discussed in [5]. An overview of different optimization algorithms for HRES and different types of objective functions that are considered while designing such systems is discussed in [6]. Another important aspect of HRES is the scheduling of power system, so that the power industry runs smoothly. A technique for tri-generation-based hybridized power plant scheduling, in the presence of energy storage facilities, which will ensure the minimum emission of pollutants and optimum utilization of fuel to meet the load demand, is discussed in [7]. Similarly, optimal operation of renewable energy micro-grids by increasing the reliability and resilience of interconnected micro-grids to cater the uncertainties and minimizing the operational cost using the technique of Hong's 2-point estimate method (PEM) for simultaneously demand response (DR) and reconfiguration scheduling is discussed in [8]. Another approach which focuses on reliability planning of micro-grids by using an integrated method which relies on clever cooperation of time ratebased demand response programs and heterogeneous DERs deployment is elaborated in [9].

A robust optimization approach, to optimally design micro-grids, which examines the economic and reliable structure for micro-grid distribution and optimal planning of DERs with section and tie switch allocation to determine micro-grid boundaries and topologies, is discussed in [10]. Similarly, risk-based planning of micro-grids under uncertainty using optimal bi-level model in which upper level corresponds to optimal planning of DER and lower level corresponds to optimum switch allocation problem for partitioning traditional distribution system into a number of micro-grids is presented in [11]. Another paper [12] proposes a new game theoretic model based on Stackelberg equilibria to determine optimal participation of MG aggregators in the retail market in order to increase its own profit simultaneously. In addition, the proposed model considered emergency demand response programming (EDRP) in the retail side of the MGs to capture the risk of participation in the retail market. Another researcher in [13] discusses the operational optimization by developing the strategies of energy management for the generation and demand side to meet the demand for electricity while minimizing the environmental and operating cost. One such HRES for a village Tattapani in AJK is discussed in this paper. The system will have a geothermal plant acting as base load plant complemented by solar and wind power plants [14]. One of the important aspects of this research is to model a geothermal plant in Homer because there is no built-in geothermal plant option available in Homer. Load dispatch strategy of the system will be such that it ensures the energy supplied on cheaper rates. By using the grid facility on a monthly net metering base, high demand of energy will easily be catered when the generation of the designed plant will not be enough. In this paper, an attempt has been made to minimize the net present cost of the system and to decrease the COE. Sensitivity analysis of COE and NPC to the constraints such as solar irradiation, wind speed and interest rate is done as well.

\section{Study area}

Pakistan is blessed with many renewable resources including geothermal resources which are capable of producing electricity [15]. There are numerous geothermal resources in Pakistan, but most of them have the temperature quite low for the production of electricity; only a few of the resources meet the requirements for the production of electricity $[16,17]$. One such resource is in Tattapani village of AJK. It is located at $33.612^{\circ} \mathrm{N} 73.947^{\circ} \mathrm{E}$ and is $26 \mathrm{~km}$ away from Kotli city in AJK.

As far as geothermal hot springs of Tattapani are concerned, they have the reservoir temperature of $140{ }^{\circ} \mathrm{C}$ measured from $\mathrm{Na}-\mathrm{K}-\mathrm{Mg}$ geo-thermometer, while its surface temperature varies from 60 to $65^{\circ} \mathrm{C}$. From the field observations, it was revealed that the flow rate of the reservoir varies from 4.3 to 11.8 I per second. Table 1 provides the flow rate and average temperature of the reservoir [18]. 
Table 1 Temperature and flow rate

\begin{tabular}{ll}
\hline Average temperature $\left({ }^{\circ} \mathrm{C}\right)$ & Flow rate $(\mathrm{I} / \mathrm{min})$ \\
\hline 140 & $270-700$
\end{tabular}

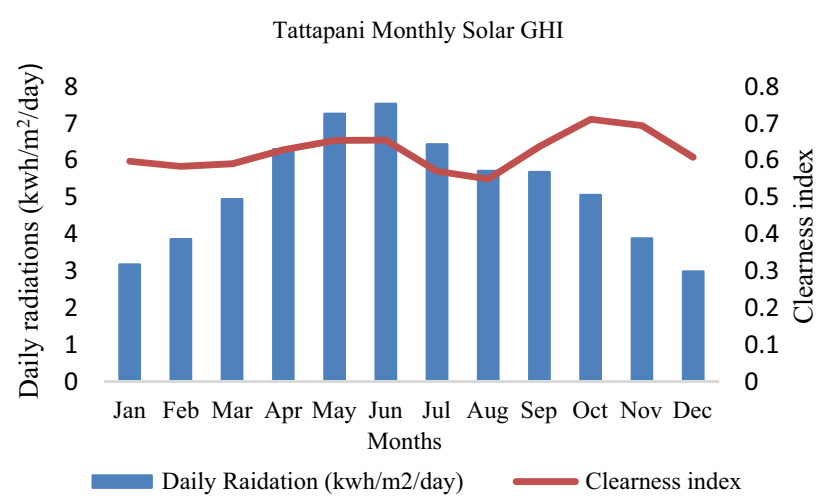

Fig. 1 Tattapani monthly solar GHI

Total energy of the hot springs at this temperature and flow rate can be easily found out using formula:

$E=\Delta T * \varphi * V$

where $E=$ energy, $\Delta T=$ temperature difference of the resource, $\varphi=$ specific heat of the water, $V=$ flow rate of reservoir.

Considering the above-mentioned specifications,

$E=(140-65) * 4200 * 4.3 \mathrm{l} / \mathrm{s}$

$E=1354 \mathrm{~kJ} / \mathrm{s}=1354 \mathrm{KW}$

the highest conversion efficiency of geothermal plants recorded is $21 \%$. Considering $20 \%$ efficiency, it can produce power approximately up to $270 \mathrm{~K}$ [19].

At this flow rate and temperature, binary geothermal plants are feasible to design as other types of geothermal plants demand high temperature and high flow rate [20]. For binary geothermal plants, working fluid will be a low boiling liquid, i.e., iso-butane or propane, etc. Different binary geothermal plants were already designed in the world on the resources of similar nature [21-24].

Pakistan is also present in that area of the world having high solar irradiance. The average solar irradiance in Tattapani village is $5.24 \mathrm{kWh} / \mathrm{m}^{2} /$ day, which is higher than required for solar power production. The average monthly solar irradiance of this area is given in Fig. 1. Temperature also affects the output of the solar panels as its efficiency decreases with the increase in temperature. So, the temperature effect is also taken care off. Table 2 provides the monthly average temperature of this area [25].

Northern areas of Pakistan have the potential to produce electricity by utilizing wind energy too. Average wind
Table 2 Tattapani monthly temperature

\begin{tabular}{ll}
\hline Month & $\begin{array}{l}\text { Average daily } \\
\text { temperature } \\
\left({ }^{\circ} \mathrm{C}\right)\end{array}$ \\
\hline Jan & 6.94 \\
Feb & 8.97 \\
Mar & 13.9 \\
Apr & 20.08 \\
May & 24.88 \\
Jun & 27.6 \\
Jul & 25.73 \\
Aug & 24.2 \\
Sep & 22.41 \\
Oct & 18.64 \\
Nov & 13.96 \\
Dec & 9.27 \\
\hline
\end{tabular}

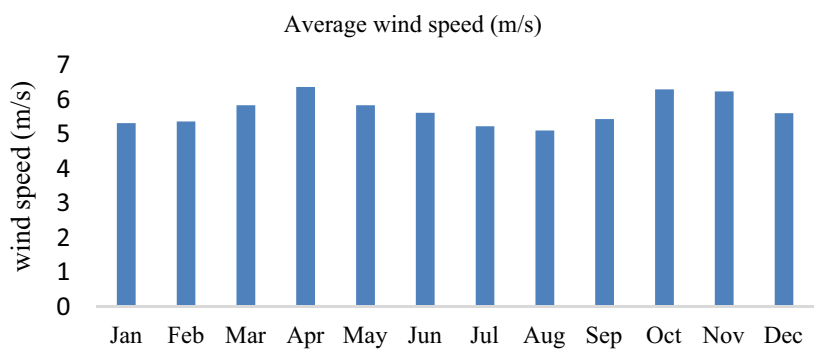

Fig. 2 Tattapani monthly average speed of wind

speed of Tattapani village located at 2237 feet above sea level is $5.69 \mathrm{~m} / \mathrm{s}$, which is effective in producing electricity via a wind turbine. Tattapani monthly wind speed in meters per second is shown in Fig. 2 [25].

\section{System description}

Homer software, which is being used for simulation and optimization, required some of the input data with respect to the specific area. Below is the detail of the data [26].

\subsection{Load profile}

The considered area is basically a village with mostly residential load. Presently, the estimated average daily energy requirement of Tattapani village is $5310 \mathrm{kWh}$, which is calculated in Table 3. As the system is being modeled for 15 years, it is designed for the generation capacity of $7350 \mathrm{kWh} /$ day by keeping in mind the future increase in demand of energy which has been forecasted on the basis of the previous trend. This load profile is arranged on the basis of the total highest demand per day, i.e., $7350 \mathrm{kWh} /$ 
Table 3 Tattapani average daily load

\begin{tabular}{|c|c|c|c|c|c|}
\hline \multirow[t]{2}{*}{ Description } & \multirow[t]{2}{*}{ Quantity } & \multicolumn{2}{|c|}{ Power (KW) } & \multirow{2}{*}{$\begin{array}{l}\text { Average } \\
\text { period }(h)\end{array}$} & \multirow{2}{*}{$\begin{array}{l}\text { Total } \\
\text { demand } \\
\text { (Kwh) }\end{array}$} \\
\hline & & $\begin{array}{l}\text { Demand } \\
\text { per unit }\end{array}$ & Total & & \\
\hline Primary schools & 5 & 2 & 10 & 6 & 60 \\
\hline $\begin{array}{l}\text { Secondary } \\
\text { schools }\end{array}$ & 4 & 3 & 12 & 6 & 72 \\
\hline Colleges & 2 & 5 & 10 & 6 & 60 \\
\hline $\begin{array}{l}\text { Government } \\
\text { offices }\end{array}$ & 6 & 3 & 18 & 7 & 126 \\
\hline Dispensaries & 3 & 2 & 6 & 12 & 72 \\
\hline Banks & 3 & 5 & 15 & 8 & 120 \\
\hline Households & 600 & 0.5 & 300 & 14 & 4200 \\
\hline Others & - & - & 100 & 6 & 600 \\
\hline Total & 623 & - & - & - & 5310 \\
\hline
\end{tabular}

day. As the maximum chunk of the total load is residential one so morning and evening are the peak load periods. Daily load profile of the area is presented in Fig. 3. The monthly load profile is presented in a whisker plot in Fig. 4. In this graph, top of the line shows the monthly maximum value and the line at the bottom shows the overall minimum value of the month. The blue box top shows the average of daily maximum values of all the days in a month, while the blue box bottom shows the average daily minimum value. The middle line corresponds to the average value of the whole month.

\subsection{Geothermal plant}

As it has been already described that for this particular resource binary geothermal plant is suitable where working fluid will be some low boiling liquid which will be
Fig. 3 Daily load profile of Tattapani

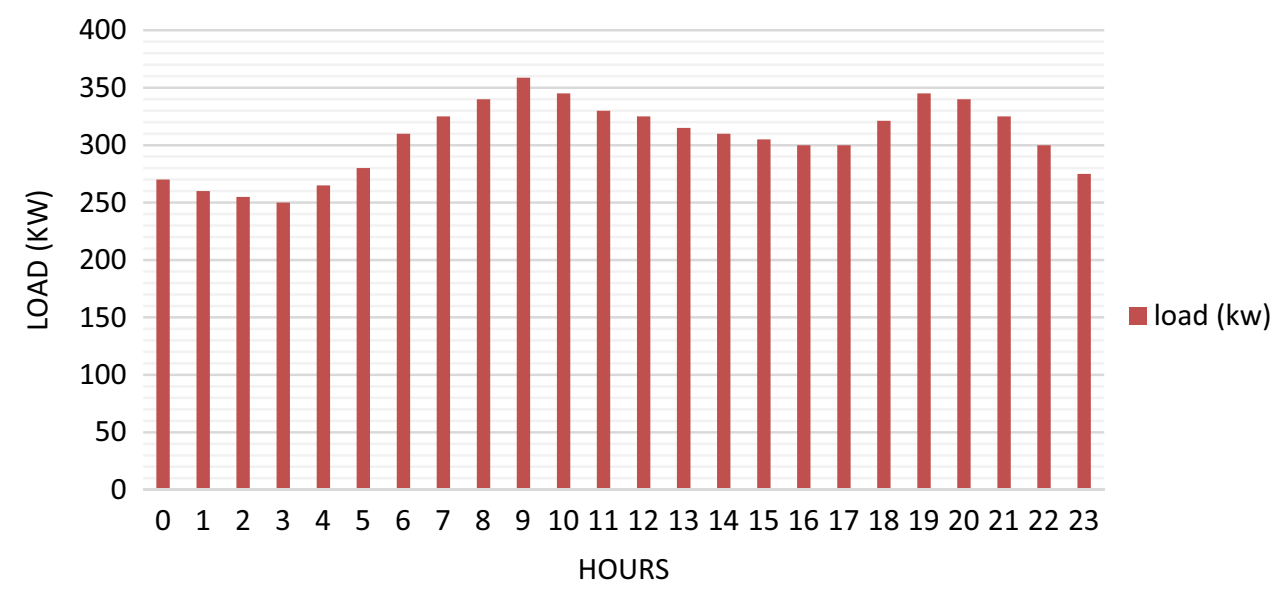

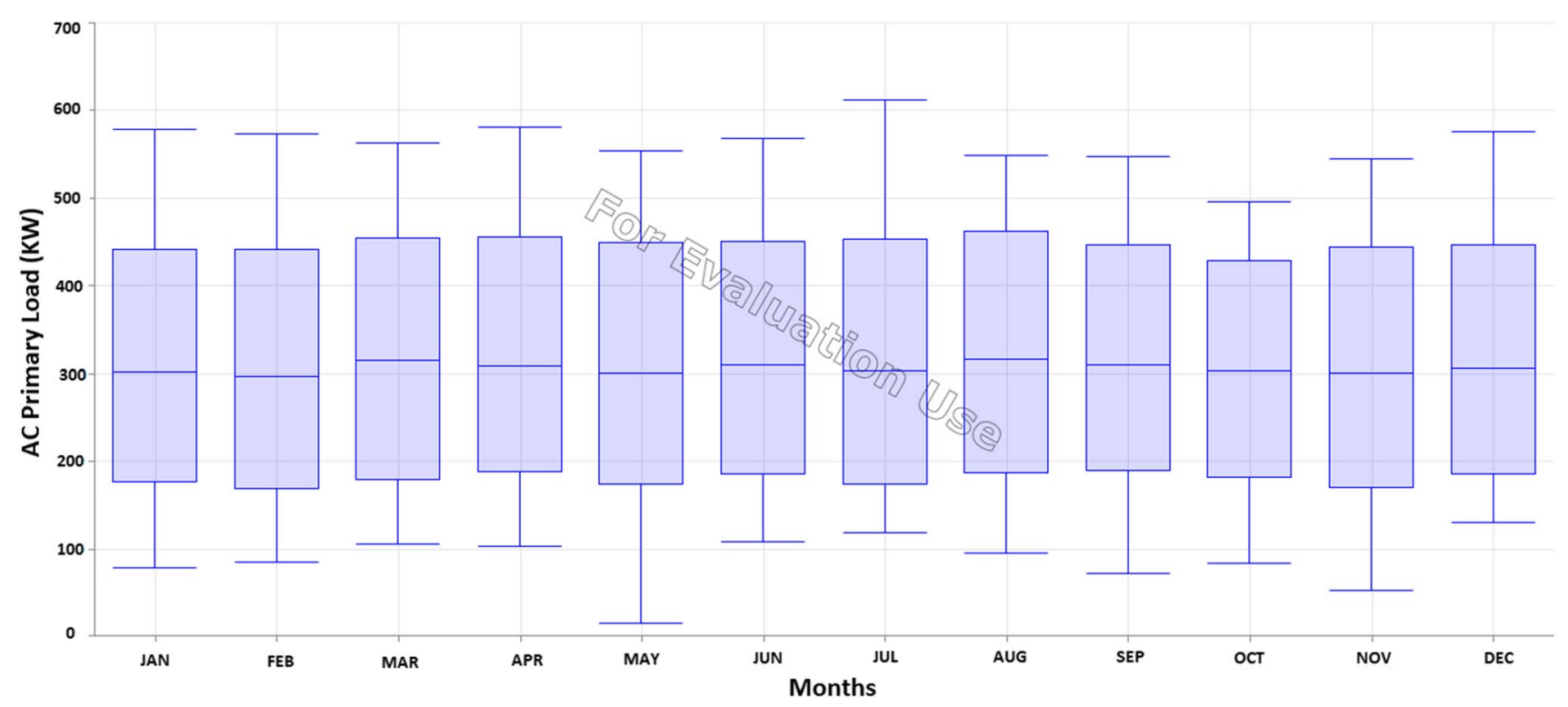

Fig. 4 Average monthly load profile 
Table 4 Geothermal power plant

\begin{tabular}{ll}
\hline Capacity (Kw) & 250 \\
Capital cost (Rs) & $55,000,000$ \\
O\&M cost (Rs/h) & 550 \\
Lifetime (years) & 15 \\
Replacement (Rs) & $\mathrm{Nil}$ \\
\hline
\end{tabular}

converted into steam by perfectly designed heat exchangers. Geothermal plant will act as a base load plant, and considering the resource size as explained through Eq. (1), one unit of 250-kw geothermal plant is considered in this design. To design a geothermal plant in Homer that produces steady power, a new generator with the fuel name as steam or hot water was created. In order to ensure the carbon-free nature of geothermal fuel, characteristics of fuel were changed to mimic the geothermal fuel characteristics. Cost of the fuel was taken as zero. The whole system will be designed for 15 years. Complete cost details of the plant are presented in Table 4 [27-29].

\subsection{Photovoltaic array}

Flat-plate photovoltaic modules are being used in the design of this hybrid renewable energy system. As temperature also affects the solar power generated from these modules, the coefficient for temperature for these modules is $-0.5 \%$ per degree increase in temperature above the nominal working temperature of a solar panel. The efficiency of these modules is $13 \%$, while these modules will have a default tilt angle of $33.61^{\circ}$. Derating factor of the system is taken as $80 \%$. Derating factor accounts for the factors that affect the total output of the panels directly or indirectly such as panels soiling, aging, shading, covering by snow and losses in the wiring. The total output power of the solar array is calculated using the equation below.

$P_{\mathrm{pv}}=f_{\mathrm{pv}} Y_{\mathrm{pv}} \frac{I_{T}}{I_{S}}$

where $f_{\mathrm{pv}}$ is the PV derating factor, $Y_{\mathrm{pv}}$ is the rated capacity of $\mathrm{PV}$ array in $\mathrm{KW}, I_{T}$ is the GHI incident of the surface of $\mathrm{PV}$ array, $I_{S}$ is the standard amount of radiations set to rate the capacity of PV array.

To generate solar power from the available resource, three PV systems are considered with the capacity of 150 kw, $200 \mathrm{kw}$ and $250 \mathrm{kw}$. Middle-East automation and controls services are approached for quotations of such a system. Capital cost is taken as $0.84 \$$ /watt, while operation and maintenance cost are taken as $0.02 \$ / w$. As the life of these modules is taken as 15 years, no replacement will be required; capital and O\&M cost for these systems are presented in Table $5[30,31]$.
Table 5 Photovoltaic power plant

\begin{tabular}{llll}
\hline Capacity (kw) & 150 & 200 & 250 \\
Capital cost (Rs) & $13,860,000$ & $18,480,000$ & $23,100,000$ \\
O\&M cost (Rs/year) & 330,000 & 440,000 & 550,000 \\
\hline
\end{tabular}

Table 6 Wind turbine

\begin{tabular}{llll}
\hline Capacity (kw) & 100 & 150 & 200 \\
Capital cost (Rs) & $16,500,000$ & $24,750,000$ & $33,000,000$ \\
O\&M cost (Rs/year) & 341,000 & 511,500 & 682,000 \\
\hline
\end{tabular}

\subsection{Wind turbines}

Three wind turbines of $100 \mathrm{Kw}, 150 \mathrm{Kw}$ and $200 \mathrm{Kw}$ capacity are used to model this system. Turbine cost is usually $70 \%$ of the total cost of wind plant, while O\&M is $3 \%$ of the turbine cost. Wind turbines' expected life in this system is taken as 15 years. So, no replacement is taken under consideration. Hub height is taken as $50 \mathrm{~m}$, while the overall loss factor that includes availability, turbines performance, environmental, wake effect and electrical loss is taken as $12.33 \%$. Table 6 shows the details of capital required by taking capital cost $1.5 \$ / \mathrm{W}$ and O\&M cost $0.31 \$ / \mathrm{W}$. The total output power of a wind turbine in Homer is calculated in four steps [31-33].

1. Determining the average wind speed by referring to the wind resource data.

2. Calculation of wind speed at the selected hub height of the turbine using logarithmic or power law.

3. Referring to the turbines' power curve to calculates its output power at the specific wind speed assuming standard air density of $1.225 \mathrm{~kg} / \mathrm{m}^{3}$.

4. Homer multiplies the power output with the air density ratio, which is the ratio of actual air density to standard air density.

\subsection{Converter}

Converter size for this specific system is chosen higher than the rated capacity of the solar panel. Now as solar panels used in this system have the maximum capacity of $250 \mathrm{kw}$ so converter of approximately $20 \%$ higher capacity installed is of $300 \mathrm{kw}$. Cost of the converter is expected to be USD54500. Table 7 provides the technical specifications.

\subsection{Grid}

In an on-grid design, grid acts as a standby power component or acts as an absorber of power which means that it will 
Table 7 Converter

\begin{tabular}{llll}
\hline Equipment & Capacity & Voltage & Efficiency \\
\hline Converter & $350 \mathrm{Kw}$ & $480 \mathrm{v} \mathrm{dc}$ & $90-95 \%$ \\
\hline
\end{tabular}

supply power to the said area when there is demand higher than the generation of designed power plant and it will purchase power from the system when there is an excess generation by the designed power plant. This sale and purchase will be done on net metering base, and for this purpose sale and purchase capacity of grid is taken as maximum.

\section{Methodology}

Homer software, used in this paper, simulates different renewable energy system configurations and portrays it with reference to the total cost of installation and operation throughout lifetime of the project, which is also called as net present cost (NPC). Depending upon the user, Homer will simulate a system for all feasible combinations of the components. Similarly, upon how users set up a problem, can simulate hundreds or even thousands of times [34].

\subsection{Cost analysis procedure by Homer}

It is an optimization tool which simulates and scales different renewable energy resources. The scaling is done on the basis of the net present cost of the system which is the lifetime system's operating and installation cost. The calculation reaches to all types of costs including the initial capital required, the replacement cost of any component, if required, throughout the projects life, fuel cost and maintenance cost of the system. It assumes the same rate escalation in all prices and applies annual interest rate too. Previously, researchers also used this software for the analyses of HRES. The input data that is required in Homer are the mean values of solar irradiation and wind speed on an hourly basis, load profile, cost data and technical details of wind turbines, solar panels, geothermal generators and converters. Different types of economic constraints, system controls and other constraints are also the inputs to the Homer. The flowchart in Fig. 5 shows Homer algorithm in detail. Following are the equations that are used to find the results [34, 35].
Fig. 5 Flowchart of software algorithm

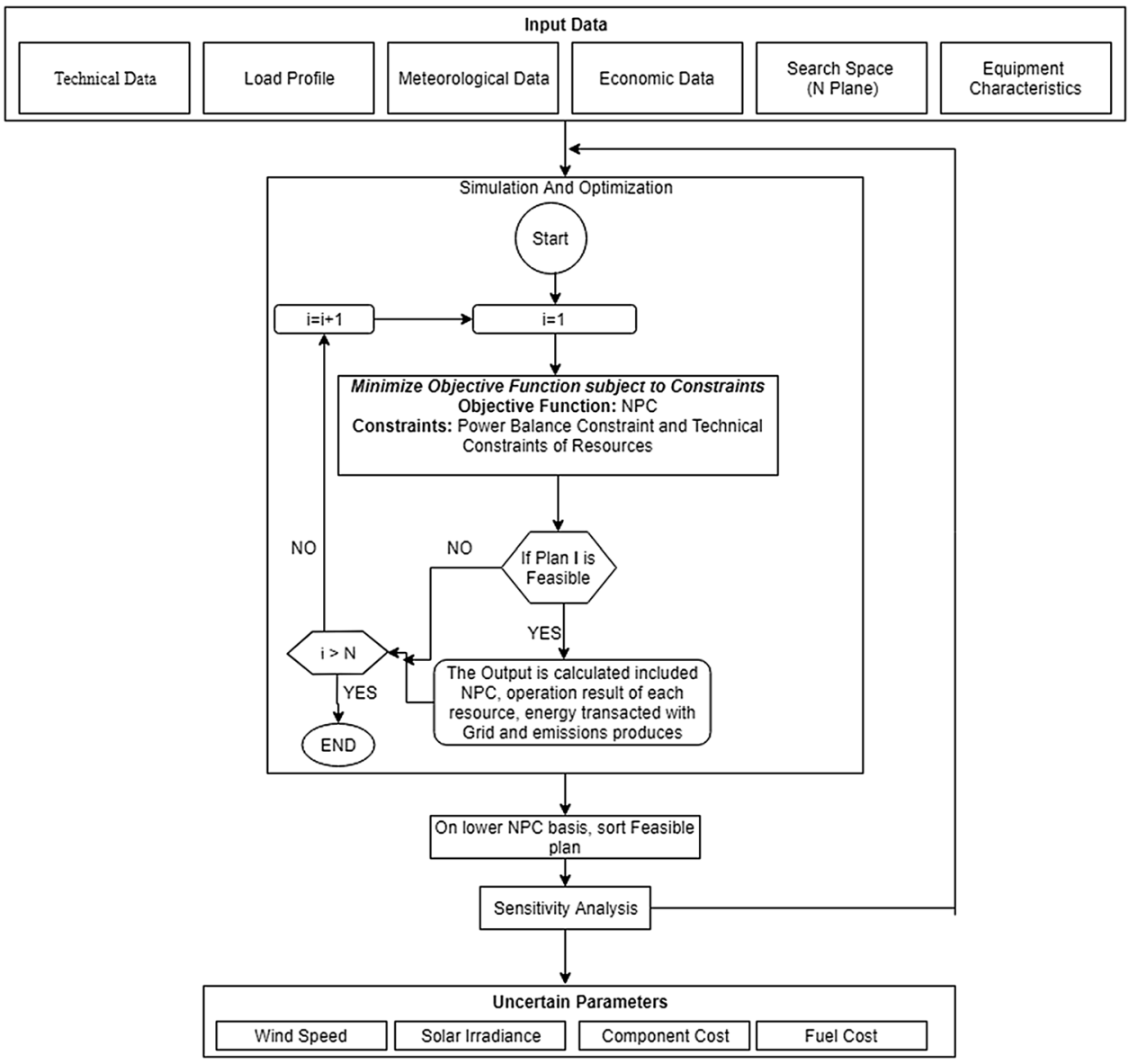




\subsubsection{Total annualized cost}

Total cost of every equipment of the system including installation, operation and maintenance, replacement and fuel cost per year is called the total annualized cost.

\subsubsection{Capital recovery factor (CRF)}

Capital recovery factor is a ratio which calculates the present value of the annuity. The equation for CRF calculation is below:

Capital recovery factor $\operatorname{CRF}(i, N)=\frac{i(1+i)^{N}}{(1+i)^{N}-1}$

where $n$ is the number of years and $i$ is the annual real interest rate. Interest rate is taken as 5\%, and expected project life is taken as 15 years in this paper.

\subsubsection{Net present cost (NPC)}

This is the total installation and operating cost of the system in the total life of the project. It is the main objective function which is to be minimized.

$\mathrm{NPC}=\frac{T_{\mathrm{ac}}}{\operatorname{CRF}\left(i, R_{\mathrm{prj}}\right)}$

where $T_{\mathrm{ac}}$ is the total annualized cost, CRF is capital recovery factor, $i$ is the percentage interest rate and $R_{\text {prj }}$ is project lifetime in years.

\subsubsection{Cost of energy (COE)}

It is the average cost/kWh of useful electrical energy produced. COE is calculated with the help of below formula.

Cost of energy $(\mathrm{COE})=\frac{T_{\mathrm{ac}}}{E_{\text {served }}}$

where $T_{\mathrm{ac}}$ and $E_{\text {served }}$ are the total annualized cost and annual total electrical load served, respectively.

\section{Optimization results}

Figure 6 shows the model for an on-grid system designed in Homer. This system is modeled as per the above-mentioned components' specifications. By considering the requirement of energy $7350 \mathrm{kWh} /$ day after keeping in view the future growth of energy demand, simulation is being carried out for the model. Homer simulates the number of

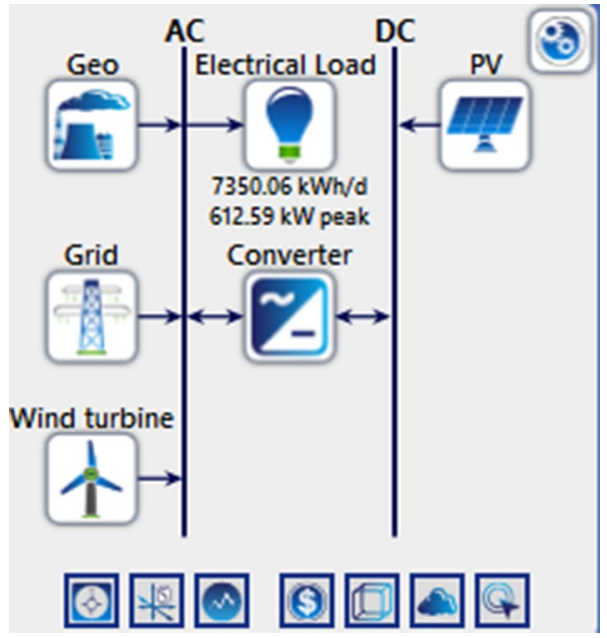

Fig. 6 On-grid hybrid geothermal-PV-wind system

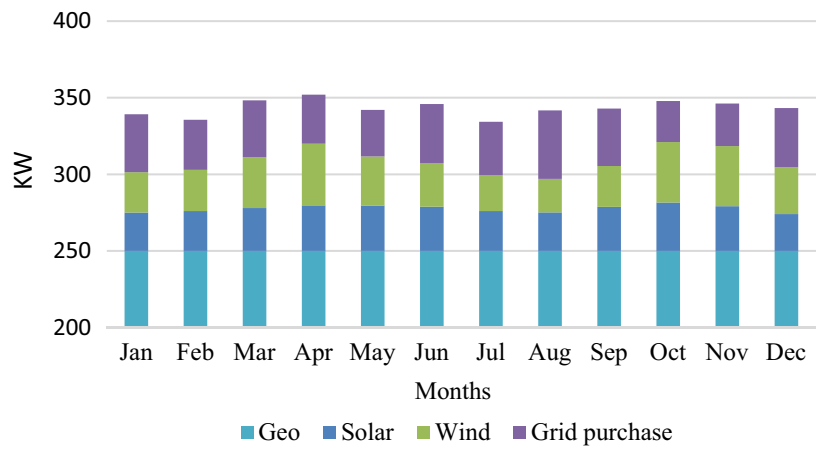

Fig. 7 Monthly electricity generation of configuration A

combinations by varying the ratings of the components as mentioned earlier. For this system, geothermal, PV and wind resources in an on-grid fashion are simulated. A large number of results are acquired, but we are going to discuss the three most important results on practical grounds which are the annual electrical energy produced and its net present cost. The cost of each productive kilowatt hours is calculated along with initial capital, operating cost and net present cost of the system.

\subsection{Configuration A}

Grid-tied 250-kw geothermal, 200-kw wind and 150-kw solar is selected as first design, and simulation is being done to calculate the cost of each productive kilowatt hour along with initial capital, cost of operation and net present cost of the design. By considering minimum flow rate as per Table 1, geothermal power plant will work throughout the year. Figure 7 shows the monthly generated energy mix to satisfy the load demand. It describes the amount of energy produced by all the plants and energy purchased 
Table 8 Annual production of electricity by configuration A

\begin{tabular}{lrl}
\hline Component & Production (Kwh) & Percentage \\
\hline Geothermal & $2,190,000$ & 72.9 \\
Wind & 269,014 & 8.95 \\
PV & 243,588 & 8.11 \\
Grid purchases & 302,472 & 10.1 \\
Total & $3,005,073$ & 100 \\
\hline
\end{tabular}

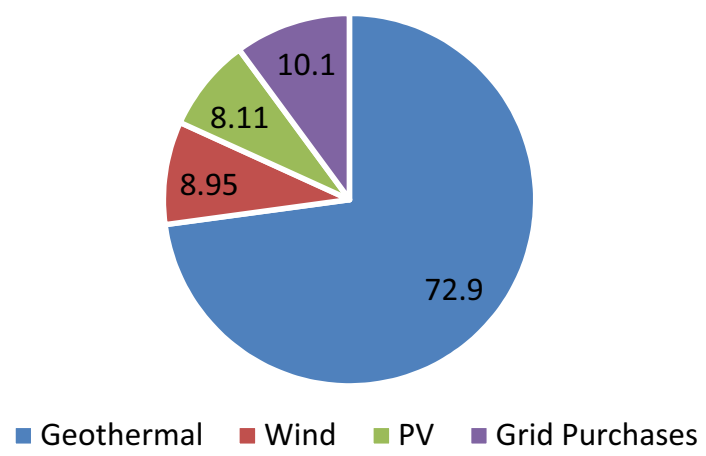

Fig. 8 Percentage production of electricity of configuration A

Table 9 Annual grid data for configuration A

\begin{tabular}{ll}
\hline Purchased & $302,472 \mathrm{kWh}$ \\
Sold & $310,122 \mathrm{kWh}$ \\
Net & $-7650 \mathrm{kWh}$ \\
Total cost & $75,703 \mathrm{Rs}$ \\
\hline
\end{tabular}

from the grid to satisfy the load demand. It is clear from the figure that as the solar and wind power production increases, the system purchases less energy from the grid. The geothermal plant is continuously supplying fix amount of power, thus acting as a base load plant. Total annual electrical production is shown in Table 8. It also shows us that the total contribution of solar and wind power is approximately $16 \%$, and the major chunk of power is supplied by the base load geothermal plant as shown in Fig. 8. By assuming energy sold and purchased rate of 8:12 rupees per kilowatt hour, respectively, it is clear from Table 9 that the net energy sold to the grid is higher as compared to the energy purchased from the grid by $7650 \mathrm{kWh}$. Hence, grid has to pay an amount of 75,703 rupees.

Annual operating cost of this system is Rs 13.2 million. Similarly, the total annualized cost of the system is Rs 23.60 million, while COE per unit is Rs7.89. Initial investment for this system Rs 108 million, while the NPC is Rs244.9 million.

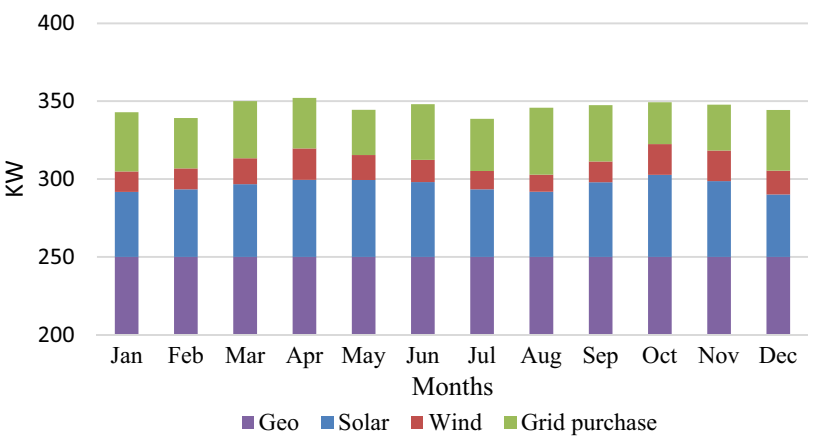

Fig. 9 Monthly electricity generation of configuration B

Table 10 Annual production of electricity configuration B

\begin{tabular}{lrl}
\hline Component & Production (Kwh) & Percentage \\
\hline Geothermal & $2,190,000$ & 72.4 \\
Wind & 134,507 & 4.44 \\
PV & 405,979 & 13.4 \\
Grid purchases & 296,291 & 9.79 \\
Total & $3,026,777$ & 100 \\
\hline
\end{tabular}

\subsection{Configuration B}

Grid-tied 250-kw geothermal, 100-kw wind and 250-kw solar is selected as second configuration, and simulation is being done for the cost of each productive kilowatt hour along with initial capital, cost of operation and net present cost of the design. By considering the minimum flow rate, geothermal power plant will work throughout the year just like the above configuration. Figure 9 shows the generated energy mix. It shows that wind turbine production decreases. This is because of its low rating. Total annual electrical production is shown in Table 10. It shows us that the total contribution of solar and wind power is approximately $17 \%$ and the major chunk of power is supplied by the base load geothermal plant as shown in Fig. 10 . Monthly grid sale and purchase cost are calculated on the same rates as in the previous case. Table 11 shows that energy sold to the grid is higher as compared to energy purchased from the grid. Assuming the previous configuration rates, the grid must pay energy charges of 150,347.2 rupees annually.

The annual operating cost of this system is Rs 12.8 million. Similarly, total annualized cost of the system is Rs22.55 million, while COE per unit is Rs7.50. Initial investment for this system Rs 101 million, while the NPC is Rs234.11 million. 


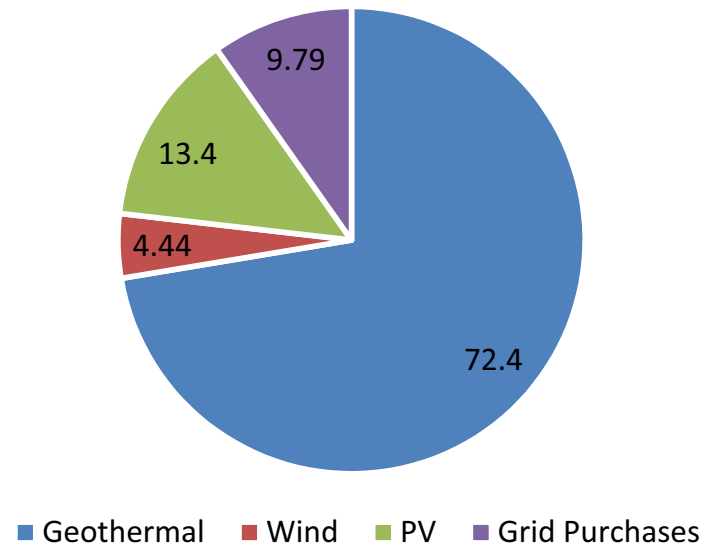

Fig. 10 Percentage production of electricity of configuration B

Table 11 Annual grid data for configuration $\mathrm{B}$

\begin{tabular}{ll}
\hline Purchased & $296,291 \mathrm{kWh}$ \\
Sold & $323,706 \mathrm{kWh}$ \\
Net & $-27,416 \mathrm{kWh}$ \\
Total cost & $-150,347 \mathrm{Rs}$ \\
\hline
\end{tabular}

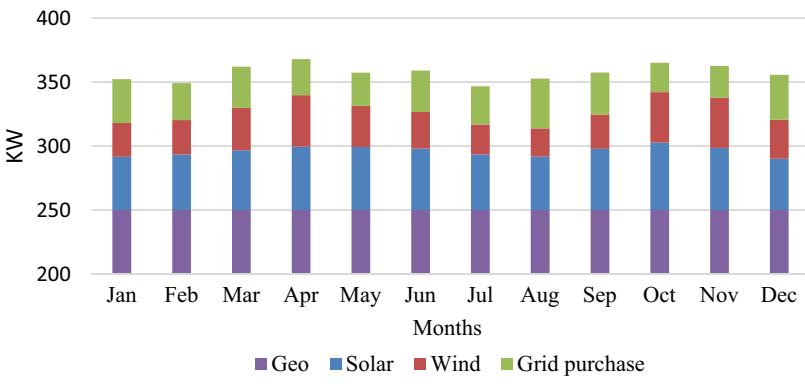

Fig. 11 Monthly electricity generation of configuration C

\subsection{Configuration C}

Grid-tied 250-kw geothermal, 200-kw wind and 250-kw solar is selected as third configuration, and simulations are being done to calculate the cost of each productive kilowatt hour along with initial capital, cost of operation and net present cost of the design. By considering the minimum flow rate, geothermal power plant will work throughout the year just like configuration A. Figure 11 shows the month-wise energy mix. High rating wind turbine and solar panels are used in this configuration, which decreases the amount of energy purchased from the grid as depicted in Fig. 11. Least energy is purchased from the grid in this configuration because equipment of high rating generates more power to satisfy the load

Table 12 Annual production of electricity by configuration C

\begin{tabular}{lrl}
\hline Component & Production (kwh) & Percentage \\
\hline Geothermal & $2,190,000$ & 70.0 \\
Wind & 269,014 & 8.60 \\
PV & 405,979 & 13 \\
Grid purchases & 262,188 & 8.39 \\
Total & $3,138,276$ & 100 \\
\hline
\end{tabular}

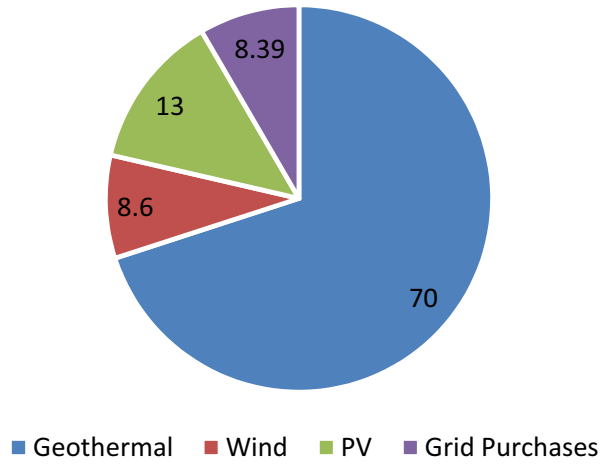

Fig. 12 Percentage production of electricity of configuration C

Table 13 Annual grid data for configuration C

\begin{tabular}{ll}
\hline Purchased & $262,188 \mathrm{kWh}$ \\
Sold & $424,111 \mathrm{kWh}$ \\
Net & $-161,923 \mathrm{kWh}$ \\
Total cost & $-1,280,341 \mathrm{Rs}$ \\
\hline
\end{tabular}

demand. Total annual electrical production is shown in Table 12. It also shows us that total contribution of solar and wind power is approximately $21 \%$ as shown in Fig. 12. Grid sale and purchase cost are calculated monthly on the same rate as in configuration A. Table 13 shows that the total energy sold to the grid is higher; hence, by assuming previous configuration rates, grid must pay extra energy charges of $1,280,341.2$ rupees annually. Annual operating cost of this system is Rs 12 million. Similarly, total annualized cost of the system is 23.35 million, while COE per unit is Rs7.52. Initial investment required for this system is Rs 118 million, while the NPC is Rs242.4 million.

It is worth mentioning here that Figs. 7, 8 and 9 show monthly energy mix to satisfy the load demand. Geothermal power remains the same throughout, while power from other plants varies in accordance with the variations of the resources. Power purchased from the grid also decreases during the months when solar and wind power increase. 
Table 14 Economic comparison of all configurations

\begin{tabular}{llll}
\hline Type of cost & Configuration A & Configuration B & Configuration C \\
\hline IC (M.Rs) & 108 & 101 & 118 \\
TAC (M.Rs) & 23.60 & 22.55 & 23.35 \\
LCOE (Rs) & 7.89 & 7.50 & 7.52 \\
NPC (M.Rs) & 244.9 & 234.11 & 242.4 \\
\hline
\end{tabular}

\section{Economic analysis}

In this research, work on an on-grid hybrid renewable energy model is discussed. Major benefits of such systems are that they not only provide electricity at cheaper rates but are also reliable as they are of an on-grid type. This system is simulated in Homer, which simulates system configurations with all the combinations of the components that are stated in the input segment. To ensure best matching of supply and demand, it performs hundreds of hourly simulations. On the basis of simulations, it proposes a list of possible solutions which are classified on the basis of NPC. The approach in these simulations is to ensure power generator delivers sufficient power to meet the load. In this paper, we have taken three results out of the number of results that were obtained.

Upon comparing these three different designs taken from all the optimization results, configuration $B$ is the most suitable design to implement. This is because the design has the lowest net present cost (NPC) of Rs234.11 million after simulating it throughout its lifetime. Hence, the payback period of this configuration will also be less. The installation cost of this selected plant is also less as compared to other designs as it uses the components of low ratings to satisfy the load demand. In terms of energy purchased from the grid, configuration $C$ purchases less energy. This configuration has equipment of high rating, so it generates more power as compared to configurations A and B. But, because of high rating equipment, its initial and $O \& M$ cost increases which eventually increase the NPC throughout the projects life. Hence, it is not regarded as the best possible configuration.

Configuration B has also the lowest COE as compared to all other configurations too. As COE is the total annualized cost divided by total load served. Load remains same in all the configurations, while the total annualized cost of configuration $B$ is less than all other configurations, which means COE of configuration $B$ is less than all other configurations. So, all other configurations are not regarded as best configurations. Results also show that per unit of cost of energy of configuration $B$ is still quite less as compared to the present per unit cost of energy in
Table 15 Ideal geothermal plant operation

\begin{tabular}{lllll}
\hline Quantity & $\begin{array}{l}\text { Operational } \\
\text { hours }\end{array}$ & Total starts & $\begin{array}{l}\text { Operational } \\
\text { life }\end{array}$ & $\begin{array}{l}\text { Capacity } \\
\text { factor }\end{array}$ \\
\hline Value & 8760 & 1 & 15 & 100 \\
Unit & h/year & Starts/year & Years & $\%$ \\
\hline
\end{tabular}

Pakistan, which is approximately $12 \mathrm{Rs} / \mathrm{kWh}$ to end user. Table 14 shows the comparison of all configurations.

\section{Geothermal as base load plant}

It is a topic of continuous debate around the globe that whether renewable energy source can serve as base load power plant or not. Base load power is that amount of power that must be generated for its customers to meet the minimum demands based on rational probability of customer requirement. As solar and wind power resources, i.e., wind speed and solar irradiance are intermittent in nature so they are able to generate electricity only when there is enough wind speed or daylight, respectively. As far as binary geothermal power plants are concerned, they are the plants with high-capacity factors. So, they are more efficient replacement of fossil fuel power plants as compared to other renewable power plants [36]. Capacity factor is the ratio of the actual amount of power generated by a plant to its capacity written on nameplate [37]. High-capacity-factor power plants are generally offline when there is a fault or during regular maintenance time. If the flow rate of the reservoir remains constant throughout, then it would efficiently generate electricity up to its rated power throughout the year. This could be done only by efficient heat exchanging mechanism between the geothermal source and working fluid that will continue throughout the year at the same rate.

In this on-grid geothermal, PV and wind hybrid system, geothermal will also act as a base load plant, generating its rated power throughout a year. Figure 8 also depicts the same behavior too as the major chunk of energy supplied to the load is by geothermal plant on a monthly basis. Table 15 also tells us the operating characteristics of this plant. Keeping a single start per year, the plant will ideally operate throughout the year and serve the load at rated capacity. To get a more practical response, shut down for scheduled maintenance and force stoppage of the plant due to any fault can also be introduced in this system. This will increase the number of starts of the plant per year. By including annual maintenance cost and severe fault clearing cost, NPC and COE will increase too. After including shutdown due to annual maintenance for 3 days and force stoppage of plant to clear out any fault if occur at different 
Table 16 Geothermal plant with regular maintenance

\begin{tabular}{lllll}
\hline Quantity & $\begin{array}{l}\text { Operational } \\
\text { hours }\end{array}$ & Total starts & $\begin{array}{l}\text { Operational } \\
\text { life }\end{array}$ & $\begin{array}{l}\text { Capacity } \\
\text { factor }\end{array}$ \\
\hline Value & 8654 & 12 & 15.2 & 98.8 \\
Unit & hrs/year & Starts/year & Years & $\%$
\end{tabular}

times of a year, the operational status of this geothermal system is given in Table 16. Load dispatch strategy is also shown in Table 17 from 2nd January $12 \mathrm{pm}$ to $4 \mathrm{pm}$ after considering an ideal situation where a geothermal plant is being operated with a single start throughout a year. It is evident from the table that geothermal power plant is working at its rated capacity, while there are variations in solar and wind plant's output power due to the intermittent nature of their sources. Similarly, this strategy of load dispatch will continue throughout the $8760 \mathrm{~h}$ of a year.

\section{Greenhouse gasses (GHG) emission}

The proposed on-grid geothermal-PV-wind powers plant in which geothermal plant will act as a base load plant will be much environment friendly as compared to the plant of a same size using diesel as fuel. As in binary geothermal plant, all the secondary fluid is in a closed loop that is not exposed to the atmosphere, while all of the geothermal fluid is returned to the reservoir. So it means binary geothermal plants across the world have essentially zero GHG emissions. The highest level of air emissions among all the geothermal plants is by open-loop flash steam plants, but it is still friendlier to the atmosphere as compared to other plants of same size, which uses fossil fuel to produce electricity. About 25 and 36 times more $\mathrm{CO}_{2}$ per $\mathrm{MWh}$ is being emitted by a coal-fired power plant than dry steam and flash steam geothermal plants, respectively [37]. Similarly, looking at the solar and wind power plants, the utilization of fuel for the production of electricity by these plants is essentially zero. So the harmful gasses being entered in the atmosphere by the production of electricity through these plants are approximately zero.
Table 18 Annual GHG emissions of diesel plant of same capacity

\begin{tabular}{lc}
\hline Name & Quantity (kg/year) \\
\hline $\mathrm{NO}$ & 1861 \\
$\mathrm{CO}$ & 9708 \\
Unburnt hydrocarbon & 515 \\
$\mathrm{CO}_{2}$ & $1,876,521$ \\
Particulate matter & 83 \\
$\mathrm{SO}_{2}$ & 4587 \\
Total quantity & $1,893,275$ \\
\hline
\end{tabular}

Now, an average diesel required to produce energy as much as this plant annually generates is 715,583 I considering $0.267 \mathrm{l} / \mathrm{kWh}$ at a plant capacity factor of $61 \%$. This estimate has been obtained by designing a plant in Homer in which there is a diesel generator serving the same amount of load as in the above case throughout a year. It can also find out approximately by multiplying total production of designed HRES system above with diesel required for one kilowatt-hour production, i.e., .267 I. Now as $1-I$ diesel emits approximately $2.63 \mathrm{~kg} \mathrm{CO}_{2}$. By multiplying it with total liters burnt to satisfy load demand, the approximate value of total $\mathrm{CO}_{2}$ emissions will be obtained. Table 18 shows the detail of gasses emitted. So essentially, the environmental benefit of this hybrid renewable energy system (HRES) is that it avoids annually 1.8 million kilogram carbon dioxide along with other flue gasses to enter into the atmosphere and deplete the ozone layer.

\section{Sensitivity analysis}

Sensitivity analysis determines how much sensitive is the dependent variable to the variations of an independent variable. This part will discuss the effect of different decision variables like wind speed, cost of energy, net present cost and total electrical production on the optimum hybrid system. As in the present design, wind and solar power contribution in total generated power depends upon the availability and intensity of their respective resources. For mean annual GHI of $5.24 \mathrm{kWh} / \mathrm{m}^{2} /$ day, energy contribution

Table 17 Load dispatch strategy for six hours

\begin{tabular}{llllllllc}
\hline Date & Time & PV output (Kw) & $\begin{array}{l}\text { Wind output } \\
(\mathrm{KW})\end{array}$ & $\begin{array}{l}\text { Geo output } \\
(\mathrm{KW})\end{array}$ & $\begin{array}{l}\text { Primary load } \\
\text { served (KW) }\end{array}$ & $\begin{array}{l}\text { Grid pur- } \\
\text { chase (Kw) }\end{array}$ & $\begin{array}{l}\text { Grid sale (KW) } \\
\text { Total load } \\
\text { served (KW) }\end{array}$ \\
\hline 2-Jan & 12:00 PM & 195.67 & 7.39 & 250 & 245.22 & 0 & 198.05 & 443.28 \\
2-Jan & 1:00 PM & 201.33 & 6.45 & 250 & 311.11 & 0 & 136.61 & 447.72 \\
2-Jan & 2:00 PM & 175.76 & 5.04 & 250 & 356.21 & 0 & 65.8 & 45.72 \\
2-Jan & 3:00 PM & 173.54 & 7.39 & 250 & 346.53 & 0 & 111.98 & 322.01 \\
2-Jan & 4:00 PM & 109.44 & 15.35 & 250 & 257.33 & 0 & 369.31 \\
\hline
\end{tabular}




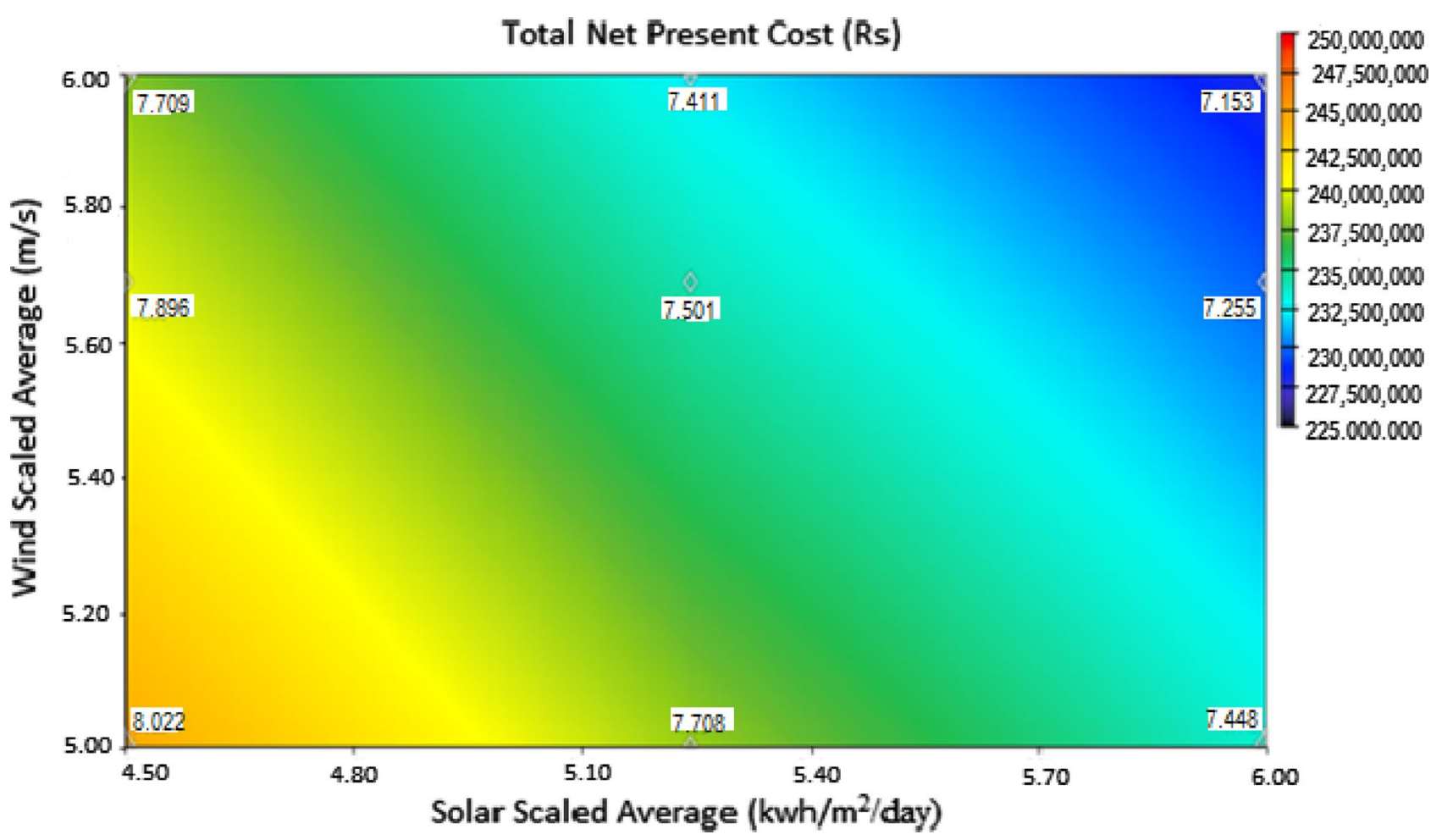

Fig. 13 Sensitivity analysis of NPC and COE at variable wind speeds and solar irradiances

by the solar power plant in this designed configuration is $13.4 \%$, while with the average annual wind speed of $5.69 \mathrm{~m} / \mathrm{s}$, wind energy contribution in total energy generation by the system is $4.44 \%$. The sensitivity analysis can also be done for future escalation of fuel prices. Sensitivity analysis can also cater to the variation in the cost of components if they are required for future expansion or replacement.

Figure 10 shows how much sensitive NPC and COE are at different wind speeds and solar irradiances. By keeping the solar irradiance at a range of $4.5 \mathrm{kWh} / \mathrm{m}^{2} /$ day to $6 \mathrm{kWh} /$ $\mathrm{m}^{2} /$ day and increasing wind speed from 5 to $6 \mathrm{~m} / \mathrm{s}$, NPC decreases from Rs 245 million to Rs 228 million keeping interest rate constant at $5 \%$. Similarly, under same conditions, COE decreases from Rs8.02 per kWh to 7.18 per kWh.

Another factor that affects the NPC and COE is the interest rate. By changing the interest rate from zero to $20 \%$ as shown in Fig. 11, NPC value changes from Rs294 million to Rs 159 million, while COE changes from Rs6.50 per kwh to Rs11.69 per kWh, as NPC is the present value of all cash that flows. Hence, by increasing the interest rate, the present value of future cash flows decreases. This basically corresponds to the idea of the time value of money. This is the reason behind decreased NPC by increasing interest rate. While on the other hand, COE increases because it is the value that is obtained by dividing total annualized cost by total load served and is thus independent of the interest rate. Hence, its value increases.

Figure 12 also shows the details that by changing the wind speed from 4.5 to $6 \mathrm{~m} / \mathrm{s}$ and by keeping GHI constant at $5.24 \mathrm{kWh} / \mathrm{m}^{2} /$ day, the total contribution of wind power increases. It results in a decrease in per unit cost of wind energy, i.e., approximately $40 \%$ decrease in LCOE is obtained by increasing wind speed up to $6 \mathrm{~m} / \mathrm{s}$. Figure 13 shows that by keeping wind speed constant at $5.69 \mathrm{~m} / \mathrm{s}$ and changing the solar irradiance from 4.5 to $6 \mathrm{kWh} / \mathrm{m}^{2}$ / day not only percentage of solar power share in total generation increases but also per unit cost of solar energy also decreases, i.e., approximately $24.62 \%$ LCOE decreases as the $\mathrm{GHI}$ increases to $6 \mathrm{kWh} / \mathrm{m}^{2} /$ day. The main reason for a change in slope is because, at the same capital cost, solar panels produce more power because of increased solar irradiance (Figs. 14, 15, 16).

\section{Conclusion}

Hybrid renewable energy systems are the only salvage to protect the environment from GHG emitted by fossil fuels used for the generation of electricity. This thesis presents the idea of utilizing geothermal, solar and wind resource of the Tattapani village in AJK in a hybridized manner with an on-grid system to meet the load demands. Binary 


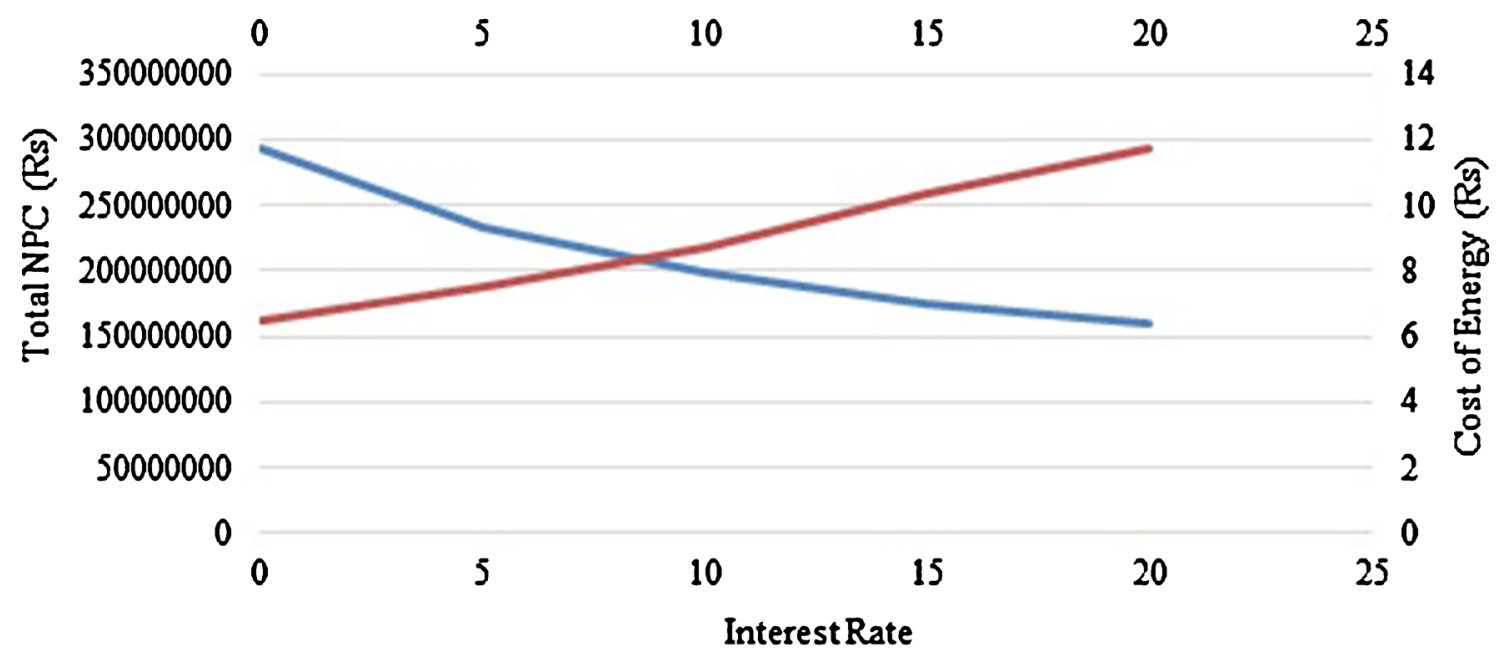

- Total Net Present Cost (Rs) - Cost of Energy (Rs)

Fig. 14 Changing interest rate impact on NPC and COE

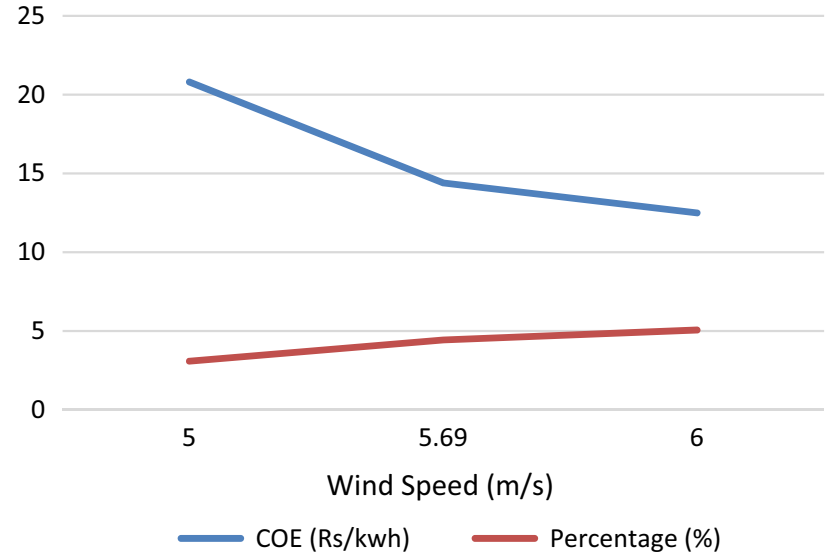

Fig. 15 Sensitivity analysis at different wind speeds and constant $\mathrm{GHI}$

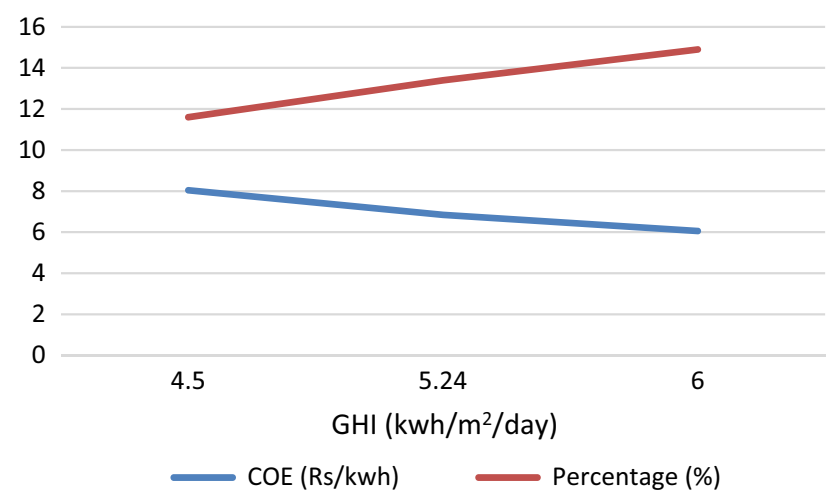

Fig. 16 Sensitivity analysis at different GHI and constant wind speed geothermal power plant is selected for this specific system as the resource temperature of $140{ }^{\circ} \mathrm{C}$ and the flow rate of minimum $270 \mathrm{l} / \mathrm{s}$ favor this type of geothermal plant. Similarly, average solar irradiance of this area is $5.24 \mathrm{kWh} /$ $\mathrm{m}^{2} /$ day, while average wind speed of this area is $5.69 \mathrm{~m} / \mathrm{s}$. Homer software is used for the cost optimization of this system. The input data that is required in Homer are the mean values of solar irradiation and wind speed on an hourly basis, load data, cost data and technical details of wind turbines, solar panels, geothermal generators and converters. Different types of economic constraints, system controls and other constraints are also the inputs to the Homer. Many results that include various combinations of the equipment are obtained. Three of the results were analyzed in this research. In each result configuration, geothermal power system is considered as a base load plant that generates $250 \mathrm{Kw}$ throughout its lifetime. This is because it has the high-capacity factor and operates throughout the year excluding the time required for regular maintenance. The best possible system with lowest net present cost of Rs 234.11 million comes out to be the one having an on-grid 250-kw geothermal power plant hybridized with 250-kw solar power system and 100-kw wind power system. The annualized cost of this system is 22.57 million rupees, while levelized cost of energy is $7.50 \mathrm{Rs} /$ KWh. Power is supplied to the load by these three hybrid power plants. As the system is on-grid type, whenever the load demand increases, then energy is purchased from the grid. The assumed rate of energy purchased from grid is 12 $\mathrm{Rs} / \mathrm{kWh}$. Similarly, whenever the generated power is higher than the load demand, the excess energy is sold to the grid at the assumed rate of $8 \mathrm{Rs} / \mathrm{kwh}$. This system also avoids 
1.8 million kilogram $\mathrm{CO}_{2}, 9708 \mathrm{~kg}$ of carbon monoxide and $1861 \mathrm{~kg}$ Nitrogen oxide entering into the atmosphere per year that could not be avoided if we use a power plant of same capacity operated on fossil fuel.

Finally, the sensitivity analysis shows that if in the future average wind speed and GHI increase, then there is also an increasing behavior in the wind and solar power contribution in the total power generated by the system. By increasing wind speed from 4.5 to $6 \mathrm{~m} / \mathrm{s}$ and keeping GHI constant, cost of wind energy decreases from 20.08 to 12.5 $\mathrm{Rs} / \mathrm{kWh}$. Similarly, when the average $\mathrm{GHI}$ increases from 4.5 to $6 \mathrm{kWh} / \mathrm{m}^{2} /$ day and by keeping wind speed constant, COE of solar power decreases from 8.04 to $6.06 \mathrm{Rs} / \mathrm{kWh}$. If wind speed and GHI changes at a same time from 5 to $6 \mathrm{~m} / \mathrm{s}$ and $4.5 \mathrm{kWh} / \mathrm{m}^{2} /$ day to $6 \mathrm{kWh} / \mathrm{m}^{2} /$ day, respectively, NPC decreases from Rs 245 million to Rs 228 million keeping interest rate constant at $5 \%$. Similarly, under same conditions, COE decreases from Rs8.02 per kWh to 7.18 per $\mathrm{kWh}$. Another important result is obtained by varying the interest rate of the whole system from 0 to $20 \%$ and it was evident from the results that overall NPC decreased from Rs294 million to Rs159 million and COE decreased from Rs6.50 Rs/kWh to $11.69 \mathrm{Rs} / \mathrm{kWh}$. Optimization and analysis of this system are done on the basis of lowest net present cost but still a lot of work can be done in analyzing HRES systems in terms of analyzing the technical feasibility of HRES and by incurring peak and off-peak rates during cost analysis. Real-time grid rates can also be used in the system. Work could be done to analyze the system by optimizing the LCOE.

\section{Compliance with ethical standards}

Conflict of interest On behalf of all authors, the corresponding author states that there is no conflict of interest.

\section{References}

1. Metz OD, Coninck HD, Loos M, Meyer L (2005) IPCC special report on carbon dioxide capture and storage. Intergovernmental Panel on Climate Change, Geneva (Switzerland). Working Group III

2. Sims REH, Rogner HH, Gregory K (2003) Carbon emission and mitigation cost comparisons between fossil fuel, nuclear and renewable energy resources for electricity generation. Energy policy 31(13):1315-1326

3. Jung J, Villaran M (2017) Optimal planning and design of hybrid renewable energy systems for microgrids. Renew Sustain Energy Rev 75:180-191

4. Kolhe ML, Ranaweera KI, Gunawardana AS (2015) Techno-economic sizing of off-grid hybrid renewable energy system for rural electrification in Sri Lanka. Sustain Energy Technol Assess 11:53-64
5. Belmili H, Haddadi M, Bacha S, Almi MF, Bendib B (2014) Sizing stand-alone photovoltaic-wind hybrid system: techno-economic analysis and optimization. Renew Sustain Energy Rev 30:821-832

6. Ghofrani M, Hosseini NN (2016) Optimizing hybrid renewable energy systems: a review. In: Sustainable energy-technological issues, applications and case studies. InTechOpen

7. Pazheri FR (2015) Tri-generation based hybrid power plant scheduling for renewable resources rich area with energy storage. Energy Convers Manag 103:717-725

8. Gazijahani FS, Salehi J (2018) Integrated DR and reconfiguration scheduling for optimal operation of microgrids using Hong's point estimate method. Int J Electr Power Energy Syst 99:481-492

9. Gazijahani FS, Salehi J (2018) Reliability constrained two-stage optimization of multiple renewable-based microgrids incorporating critical energy peak pricing demand response program using robust optimization approach. Energy 161:999-1015

10. Gazijahani FS, Salehi J (2018) Robust design of microgrids with reconfigurable topology under severe uncertainty. IEEE Trans Sustain Energy 9(2):559-569

11. Gazijahani FS, Salehi J (2018) Optimal bilevel model for stochastic risk-based planning of microgrids under uncertainty. IEEE Trans Ind Inform 14(7):3054-3064

12. Gazijahani FS, Salehi J (2018) Game theory based profit maximization model for microgrid aggregators with presence of EDRP using information gap decision theory. IEEE Syst J 99:1-9

13. Wang Xiaonan, Palazoglu Ahmet, El-Farra Nael H (2015) Operational optimization and demand response of hybrid renewable energy systems. Appl Energy 143:324-335

14. Sovacool BK (2009) The intermittency of wind, solar, and renewable electricity generators: technical barrier or rhetorical excuse? Utilities Policy 17(3):288-296

15. Awan $A B$, Khan ZA (2014) Recent progress in renewable energy-remedy of energy crisis in Pakistan. Renew Sustain Energy Rev 33:236-253

16. Mustaqeem SA, Qureshi SR, Waqar A (2015) Exergetic and energetic analysis of power generation from geothermal resources in Pakistan. In: Proceedings World Geothermal congress, 19-25 April 2015

17. Zaigham NA, Nayyar ZA, Hisamuddin N (2009) Review of geothermal energy resources in Pakistan. Renew Sustain Energy Rev 13(1):223-232

18. Anees M, Shah MM, Qureshi AA (2015) Isotope studies and chemical investigations of Tattapani hot springs in Kotli (Kashmir, NE Pakistan): implications on reservoir origin and temperature. Procedia Earth Planet Sci 13:291-295

19. Zarrouk SJ, Moon H (2014) Efficiency of geothermal power plants: a worldwide review. Geothermics 51:142-153

20. Franco MV (2009) Optimal design of binary cycle power plants for water-dominated, medium-temperature geothermal fields. Geothermics 38(4):379-391

21. Rafferty K (2000) Geothermal Power Generation, a primer on low temperature small scale applications. Geo-Heat Center, Oregon Institute of Technology, Klamath Falls, OR. http://geoheat.oit. edu/pdf/powergen.pdf

22. Budisulistyo D, Wijninckx R, Krumdieck S (2015) Methodology of pre-feasibility study for a binary geothermal power plant utilizing low-moderate temperature heat sources. In: Proceedings 37th New Zealand Geothermal Workshop, vol 18, p 20

23. Kopunicova M (2009) Feasibility study of binary geothermal power plants in Eastern Slovakia: analysis of ORC and Kalina power plants. Diss

24. Lund JW, Boyd T (1999) Small geothermal power projects examples. In: GHC Bulletin 
25. National Aeronautics and Space Administration. https://eoswe b.larc.nasa.gov/cgibin/sse/retscreen.cgi?email=skip\%40lar c.nasa.gov\&step $=1 \&$ lat $=33.61 \&$ lon $=73.9466 \&$ submit $=$ Submit. Access 25 Jan 2018

26. Nurunnabi M, Roy NK (2015) Grid connected hybrid power system design using HOMER. In: International Conference on Advances in Electrical Engineering (ICAEE). IEEE, pp 18-21

27. Sanyal SK (2005) Cost of geothermal power and factors that affect it. In: Proceedings world geothermal congress, pp 24-29

28. DiPippo R (1999) Small geothermal power plants: design, performance and economics. GHC Bulletin

29. Stefansson V (2002) Investment cost for geothermal power plants. Geothermics 31(2):263-272

30. Middle east automation and controls services. www.macsp k.com

31. International Renewable Energy Agency "renewable energy technologies: cost analysis series", vol 1, Power Sector, Issue 5/5, June 2012
32. European Wind Energy Association (2009) The economics of wind energy. EWEA

33. Ragheb M (2015) Economics of wind energy. Wind Power Systems: Harvesting the wind, course NPRE 475

34. National renewable energy laboratories. www.nrel.gov/homer. Access 20 Dec 2017

35. Getting Started Guide for HOMER Version 3.3.1. https://www. homerenergy.com. Access 20 Dec 2017

36. Geothermal Energy Overview (2012) Renewables 21 global status report. The Carbon Neutral Company, USA

37. Matek B, Gawall K (2015) The benefit of baseload renewables: a misunderstood energy technology. Electr J 28(2):101-112

Publisher's Note Springer Nature remains neutral with regard to jurisdictional claims in published maps and institutional affiliations. 